\title{
Enterotoxigenic bacteria in the sudden infant death syndrome
}

\author{
W. G. MURRELL*, BETTY J. STEWART $\dagger$, CATA O'NEILL*\$, S. SIARAKAS* $\|$ and S. KARIKS $\ddagger$
}

* Department of Microbiology, University of Sydney, New South Wales 2006; †CSIRO Division of Food Processing, Delhi Road, North Ryde NSW 2113 and $\ddagger$ Division of Forensic Medicine, 42-45 Parramatta Road, Glebe NSW 2037, Australia

\begin{abstract}
Summary. Faecal samples from 123 infants who died with sudden infant death syndrome (SIDS) and from a comparative group of 52 age-matched babies were analysed for toxigenic bacteria and their toxins. Serum samples from the SIDS infants were also analysed for these toxins. A significantly higher proportion of toxigenic bacteria and their toxins were found in faecal samples of SIDS babies than in samples from the comparative group. These toxins were also found in serum from the SIDS babies. Clostridium perfringens was found in $54(45.4 \%)$ of 119 SIDS cases compared with $10(19.6 \%)$ of 51 healthy babies $\left(\chi^{2}=10 \cdot 1, \mathrm{p}<0.01\right) ; C$. difficile in $33(27.7 \%)$ of 119 SIDS cases compared with $8(14.8 \%)$ of 54 healthy babies $\left(\chi^{2}=\right.$ $\left.3.43^{\text {ns }}, p<0 \cdot 1\right) ;$ Staphylococcus aureus in $12(27 \cdot 3 \% ; 66.7 \%$ enterotoxigenic) of 44 SIDS cases compared with $12\left(85.7 \%\right.$; non-enterotoxigenic) of 14 healthy babies $\left(\chi^{2}=14.9\right.$, $\mathrm{p}<0.001)$; C. botulinum in $6(5.0 \%)$ of 120 SIDS cases compared with 0 of 53 healthy babies $\left(\chi^{2}=2 \cdot 74, \mathrm{p}<0 \cdot 1\right)$. Campylobacter jejuni, Yersinia enterocolitica, Vibrio parahaemolyticus, salmonellae and Bacillus cereus were not detected. Heat-labile toxin, lethal to mice (HLML) was found in $32(27 \cdot 1 \%)$ of 118 SIDS faecal samples compared with $5(10.6 \%)$ of 47 healthy babies $\left(\chi^{2}=5 \cdot 24, \mathrm{p}<0.05\right)$; cytotoxins in $38(30.9 \%)$ of 123 SIDS faecal samples compared with 0 of 21 of healthy babies $\left(\chi^{2}=8.8, p<0.01\right)$ and $24(27.6 \%)$ of 87 SIDS serum samples. $C$. perfringens enterotoxin was detected in $33(34.4 \%)$ of 96 SIDS faecal extracts compared with 0 of 23 of healthy babies $\left(\chi^{2}=10.94, \mathrm{p}<0.001\right)$, and in $27(24.5 \%)$ of 110 SIDS serum samples. $C$. perfringens $\alpha$-toxin (presumptive) was detected in $14(17 \cdot 5 \%)$ of 80 SIDS faecal extracts compared with 0 of 17 from healthy babies $\left(\chi^{2}=3 \cdot 5^{\text {ns }}, \mathrm{p} \bumpeq 0.05\right)$ and in $2(2 \cdot 3 \%)$ of 87 SIDS serum samples. $C$. difficile toxin was detected in four SIDS faecal samples and two serum samples. $C$. botulinum toxin was detected in only one of 120 SIDS faecal samples compared with none of 49 from healthy babies. Staphylococcal enterotoxins were detected in $8(19 \cdot 5 \%)$ of 41 SIDS faecal samples compared with 0 of 19 from healthy babies $\left(\chi^{2}=4 \cdot 278\right.$, $\mathrm{p}<0.05)$, and in $4(10.8 \%)$ of 37 SIDS serum samples. Toxigenic and non-toxigenic strains of $C$. perfringens and $C$. difficile occurred in faecal samples of both SIDS and healthy babies. Formula-fed SIDS babies had a significantly higher incidence of $C$. difficile $\left(\chi^{2}=6 \cdot 654, \mathrm{p}<\right.$ $0.01), C$. perfringens $\left(\chi^{2}=6.422, \mathrm{p}<0.05\right)$, and its enterotoxin $\left(\chi^{2}=7.787, \mathrm{p}<0.01\right)$ in faeces, and a higher incidence (non-significant) of $C$. perfringens enterotoxin in their serum, faecal HLML toxin, and $S$. aureus and its enterotoxin, than breast-fed babies. Male SIDS babies had a significantly higher incidence of $C$. perfringens $\left(\chi^{2}=7.687, \mathrm{p}<0.01\right)$ and higher incidences (non-significant) of $C$. perfringens enterotoxin, HLML toxin, $C$. difficile, and $S$. aureus and its enterotoxin than female babies. SIDS babies dying in winter had a significantly higher incidence of $C$. difficile than those dying in summer $\left(\chi^{2}=5.328, \mathrm{p}<0.05\right)$ and spring $\left(\chi^{2}=4.444, \mathrm{p}<0.05\right)$. C. perfringens, $S$. aureus and their enterotoxins occurred in more babies dying in autumn and winter than in spring and summer. The incidence of these bacteria and their toxins did not differ for position of death. These results provide some support for the idea that intestinal toxins have a pathogenic role in SIDS.
\end{abstract}

Received 2 Dec. 1991; revised version accepted 4 Jan. 1993.

* Correspondence should be sent to Dr W. G. Murrell.

$\S$ Present address: Arthur Websters Pty Ltd, Castle Hill, NSW 2154, Australia.

\| Present address: General Repatriation Hospital, Concord, NSW 2139, Australia.

\section{Introduction}

There has been mounting evidence in recent years that bacterial toxins may play a causal role in SIDS. Infant botulism, first recognised in 1976, was found to 
explain nearly $5 \%$ of SIDS cases in California ${ }^{1,2}$ and led Arnon ${ }^{3}$ to suggest that other toxigenic intestinal bacteria may be responsible for some cases. In 1978, Trube-Becker ${ }^{4}$ suggested that enteral bacterial infections may be a cause of SIDS. In SIDS cases examined in Switzerland, Sonnabend et al. ${ }^{5}$ found that samples from $15 \%$ contained Clostridium botulinum and its toxin. The study of the role of $C$. difficile and viruses by Laughon et al. ${ }^{6}$ strongly suggested that enteric pathogens may play a direct or indirect role in at least some SIDS cases.

Several more recent papers implicate toxin hypotheses. These involve $C$. perfringens toxins, ${ }^{7}$ enterotoxins and products of bacterial metabolism, ${ }^{8}$ bacterial toxins in the respiratory tract, ${ }^{9}$ toxigenic strains of Escherichia coli, ${ }^{10,11}$ pathogens in the nasopharyn $\mathrm{x}^{12}$ and possibly Chlamydia trachomatis in respiratory infections. ${ }^{13,14}$ The evidence for a "toxigenic aetiology" has been summarised recently. ${ }^{15}$

In previous studies of clostridia in SIDS babies, Laughon et al. ${ }^{6}$ detected C. difficile in $16(28 \%)$ of 58 SIDS cases and in $8 \%$ of healthy babies in numbers of $10^{3}-10^{6} \mathrm{cfu} / \mathrm{g}$. Of the SIDS faecal samples, $21 \%$ were positive for cytotoxin compared to only $4 \%$ of faecal samples from healthy babies. C. perfringens was detected in faecal samples from 6 of 10 healthy babies. ${ }^{16}$ Murrell et al. ${ }^{7}$ found C. perfringens in 19 of 34 faecal, 13 of 34 ileal and 5 of 31 pharyngeal samples from SIDS babies, in 3 of 10,1 of 8 and 0 of 7 similar samples, respectively, from dead control babies, and 4 of 22 faecal samples from healthy control babies. Growth on blood agar varied from light to heavy, presumably indicative of the variation in population levels, the levels being greater in the SIDS samples than in those of the controls. C. perfringens enterotoxin was found in 12 of 33 faecal, 6 of 33 ileal and 9 of 31 pharyngeal samples from the SIDS cases, but in only 1 of 5,1 of 5 and 0 of 3 similar samples, respectively, from dead control babies, and 1 of 22 faecal samples from healthy controls. Surprisingly, however, these authors found $C$. perfringens enterotoxin in 20 of 44 SIDS serum samples and also in 12 of 26 serum samples from control dead babies, by use of a sensitive ELISA assay.

The initial aim of the present study was to determine whether the incidence of $C$. botulinum and its toxin in SIDS babies was similar to that in California. ${ }^{1}$ It became immediately obvious that many faecal extracts were toxic to mice but that toxicity did not result from C. botulinum toxin. Therefore, the project aim ${ }^{17}$ became the identification of the nature of these toxins, and their significance and role in the SIDS.

\section{Materials and methods}

\section{Samples}

The SIDS faecal and serum samples were obtained from 123 infants examined at the Sydney Division of Forensic Medicine during 1983-1986 (period A) and during 1988-1991 (period B). They are representative of the greater metropolitan area, and met with the Beckwith $^{18}$ definition of sudden infant death; 78 agematched babies were studied in period $A$ and 45 in period $B$. Their age distribution is shown in fig. $1 B$. The median ages for periods $\mathrm{A}, \mathrm{B}$ and $\mathrm{A}+\mathrm{B}$ were 10.5 (95\% confidence limits $9-12$ weeks), 12.0 (10-12 weeks), and 12.0 (10-12 weeks) respectively. Nearly $80 \%$ of deaths occurred between 1 and 5 months, with $90 \%$ occurring under 6 months of age; $63 \%$ were males and $37 \%$ females. Bacteriological analyses were performed on a total of 166 SIDS babies (including the 123 age-matched children). The effect of the sex, sleeping position, season of death and, where available, feeding pattern on the data for incidence of bacteria and toxin was analysed for these 166 babies. Information in autopsy records and public reports shows that of the 166 SIDS babies analysed bacteriologically, three received antibiotics (one amoxycillin, two co-trimoxazole), possibly in the week before death, and $C$. perfringens $\left(\log _{10} 6 \cdot 48 / \mathrm{g}\right)$ was grown from one of these.

Blood and colonic contents or faeces were taken aseptically at autopsy. Autopsies were performed as described by $\mathrm{Kariks}^{19}$ as soon as practicable after death of the infants, $46 \%$ within $24 \mathrm{~h}, 97 \%$ within $48 \mathrm{~h}$ and $99 \%$ within $72 \mathrm{~h}$. The time from death until placement of the body in the mortuary cold room varied from 2 to $10 \mathrm{~h} .{ }^{19}$ The bodies were quite cold $\left(12-18^{\circ} \mathrm{C}\right)$ on arrival at the mortuary, but rigor mortis was present in only a few cases.

The heart blood was transferred aseptically with a small sterile spoon to a sterile centrifuge tube and stored at $0-4^{\circ} \mathrm{C}$, until centrifuged. Serum samples were stored at $-20^{\circ} \mathrm{C}$.

Colon contents were transferred to a sterile weighed container. If the colon was empty, faecal deposits on the napkin were scraped up with a sterile spoon and transferred to the container. The container was immediately placed in a type B BioBag (Marion Scientific Corporation, Kansas City, MO, USA) to maintain anaerobic conditions and stored at $0-4^{\circ} \mathrm{C}$ until examined bacteriologically.

The examinations were performed on the day of arrival of the samples at the laboratory (usually on the day the autopsy was performed) or as soon as possible thereafter. The jar containing the stool sample was weighed to obtain the stool weight and a small sample of known weight was transferred to a MacCartney bottle by the Hungate anaerobic technique of $\mathrm{CO}_{2}$ flushing. ${ }^{20}$ Nine times its weight of gelatin-phosphate buffer ${ }^{21}$ was added to produce the suspension for viable counts. Further dilutions were made with pre-reduced buffer ${ }^{20}$ and $\mathrm{CO}_{2}$ flushing. To obtain the faecal extract for toxin tests, marble chips and buffer (two or three times the weight of the remainder of the stool sample) were added, the sample was ground with a glass rod and centrifuged at $10000 \mathrm{~g}$ for $20 \mathrm{~min}$. The supernate (the faecal extract) was filtered through a $0.45-\mu \mathrm{m}$ pore membrane filter and 
used for the toxin tests. Unused faecal extract was stored at $-20^{\circ} \mathrm{C}$. The pellet was stored at $1{ }^{\circ} \mathrm{C}$ for most probable number estimates of C. botulinum ${ }^{22}$ if the toxin test indicated that the bacterium was present. Stools obtained from near-miss SIDS cases were treated similarly.

\section{Samples from healthy babies}

It was difficult to obtain specimens from suitable control babies of the same age group who died from causes other than SIDS. Most babies who died in hospitals were unsuitable as they had been treated with antibiotics, other medicants or were suffering from intestinal disorders that could affect the microbial status of their intestinal tract. Only six true controls were included with the healthy babies. Samples from age-matched healthy babies (3-44 weeks) were obtained from baby health-care centres with the kind help of the staff and mothers concerned. These babies, the "comparative group" ${ }^{12}$ were considered to give a more reliable indication of the normal microbial status of the healthy intestinal tract than babies dying from causes other than SIDS. Fifty-four age-matched babies, 31 in period A and 23 in period B, were studied. The median ages of the babies in periods $A, B$ and A + B were 13 (95\% confidence limits 10-15 weeks), 16 (10-24 weeks) and 14 (11-16 weeks) weeks, respectively, i.e., not significantly different from that of the SIDS babies. Their age distribution is shown in fig. 1A. The stool samples were transferred with sterile spoons to sterile weighed jars and the jars (with loose lids) were placed in BioBags and chilled at $2-4^{\circ} \mathrm{C}$ until transported to the laboratory. For several of the babies additional stool samples were obtained at intervals of 1-3 weeks later, to determine changes in the microbial or toxin state of the stools.

\section{Toxin tests}

Faecal extracts $(0.4 \mathrm{ml})$ and serum samples (up to $1.0 \mathrm{ml}$ ) were injected intraperitoneally into two white mice (18-20 g; Quackenbush strain) according to the standard mouse neutralisation procedure, ${ }^{21}$ to test for C. botulinum toxin. If the extract killed both mice, was heat labile but was not neutralised by $C$. botulinum type A-G antisera (a gift from Dr C. L. Hatheway, Centers for Diseases Control, Atlanta, GA, USA) it was designated heat-labile mouse lethal (HLML) toxin. The enterotoxins of $C$. perfringens, E. coli, Vibrio parahaemolyticus and Staphylococcus aureus types A, B, C and D were detected by the reverse passive latex agglutination (RPLA) kits of Denka Seiken Co. Ltd, Tokyo, used as microslide agglutination tests. Agglutination was observed with phase contrast microscopy or an Olympus inverted microscope. Some of the samples were tested for $C$. difficile toxin $\mathrm{A}$ by the HeLa cell cytotoxicity test ${ }^{23}$ and confirmed with an ELISA test kit (Meridian Diagnostics Inc., Cincinnati, OH, USA). C. sordellii antiserum (Wellcome Research Laboratories, Becken- ham) was used to neutralise the toxin. $C$. perfringens $\alpha$-toxin was detected as the cytotoxicity to HeLa cells that was neutralised by $C$. perfringens type A diagnostic serum (anti- $\alpha$ toxin) (Wellcome Diagnostics, Dartford). In the cytotoxin tests, the filtrates of faecal extracts and sera filtered through $0 \cdot 2-\mu \mathrm{m}$ pore membrane filters were added to the cell monolayers with or without antisera, incubated at $37^{\circ} \mathrm{C}$ for $48 \mathrm{~h}$ and observed for cytopathic effects. Because of the presence of more than one toxin in a sample that was capable of causing cytopathic effects it was not always possible to identify clearly the toxins in some samples by specific neutralisation even when neutralisation was performed with more than one antiserum. These samples have been recorded simply as "cytotoxin positive."

Thermal stability of the toxin was determined by heating the extract or serum at $80^{\circ} \mathrm{C}$ for $10 \mathrm{~min}$.

\section{Bacterial detection and enumeration}

The faecal samples were diluted to $10^{8}$ and plated on to specific isolation media to detect and enumerate toxigenic bacteria. The faecal samples were screened for the following aerobic bacteria grown at $37^{\circ} \mathrm{C}$ : Salmonella spp. (xylose lysine desoxycholate agar ${ }^{24}$ ); staphylococci (Baird-Parker medium ${ }^{25}$ and Mannitol Salt Agar, Oxoid); V. parahaemolyticus (thiosulphate citrate bile salts sucrose agar) $;^{26} \beta$-haemolytic streptococci (Columbia agar base, Oxoid containing defibrinated horse blood $7 \%$ and nalidixic acid $10 \mathrm{mg} / \mathrm{L}$; and Aeromonas hydrophila (Oxoid medium). Bacillus cereus (phenol red egg yolk polymyxin agar) ${ }^{27}$ and Yersinia enterocolitica (cefsulodin-irgasan-novobiocin agar) ${ }^{28}$ cultures were incubated at $30^{\circ} \mathrm{C}$. Cultures for E. coli biotype 1 ( $\operatorname{ImVic}++--$, includes enteropathogenic and enterotoxigenic serotypes) (tryptone bile agar) ${ }^{29}$ were incubated at $40^{\circ} \mathrm{C}$. Campylobacter jejuni was detected with Preston medium ${ }^{30}$ incubated in an atmosphere of $\mathrm{O}_{2} 5 \%, \mathrm{CO}_{2} 10 \%$ and $\mathrm{N}_{2} 85 \%$ at $37^{\circ} \mathrm{C}$. The faecal samples were screened for the following anaerobic toxigenic bacteria: $C$. perfringens (tryptone sulphite cycloserine agar), ${ }^{31} C$. difficile (cycloserine, cefoxitin, fructose egg-yolk agar ${ }^{32}$ incubated at $37^{\circ} \mathrm{C}$ ) and $C$. botulinum ${ }^{21}$ (botulinum selective medium $^{33}$ and cooked meat medium with glucose $0.5 \%$ incubated at $30^{\circ} \mathrm{C}$ ).

The methods for the bacterial counts were chosen to detect and enumerate significant numbers of specific bacteria. Colonies on the specific selective media were checked microscopically for type and, if necessary, confirmed by standard biochemical, serological and other confirmatory tests. ${ }^{20}$ Enrichment techniques to detect low numbers were not used except for $C$. botulinum. Toxigenicity of isolates was demonstrated by growing the bacteria in media known to support toxin production, e.g., Cooked Meat Medium (Oxoid) and Brain Heart Infusion Broth (Difco) for C. difficile and cooked meat medium and Duncan and Strong medium for $C$. perfringens. 


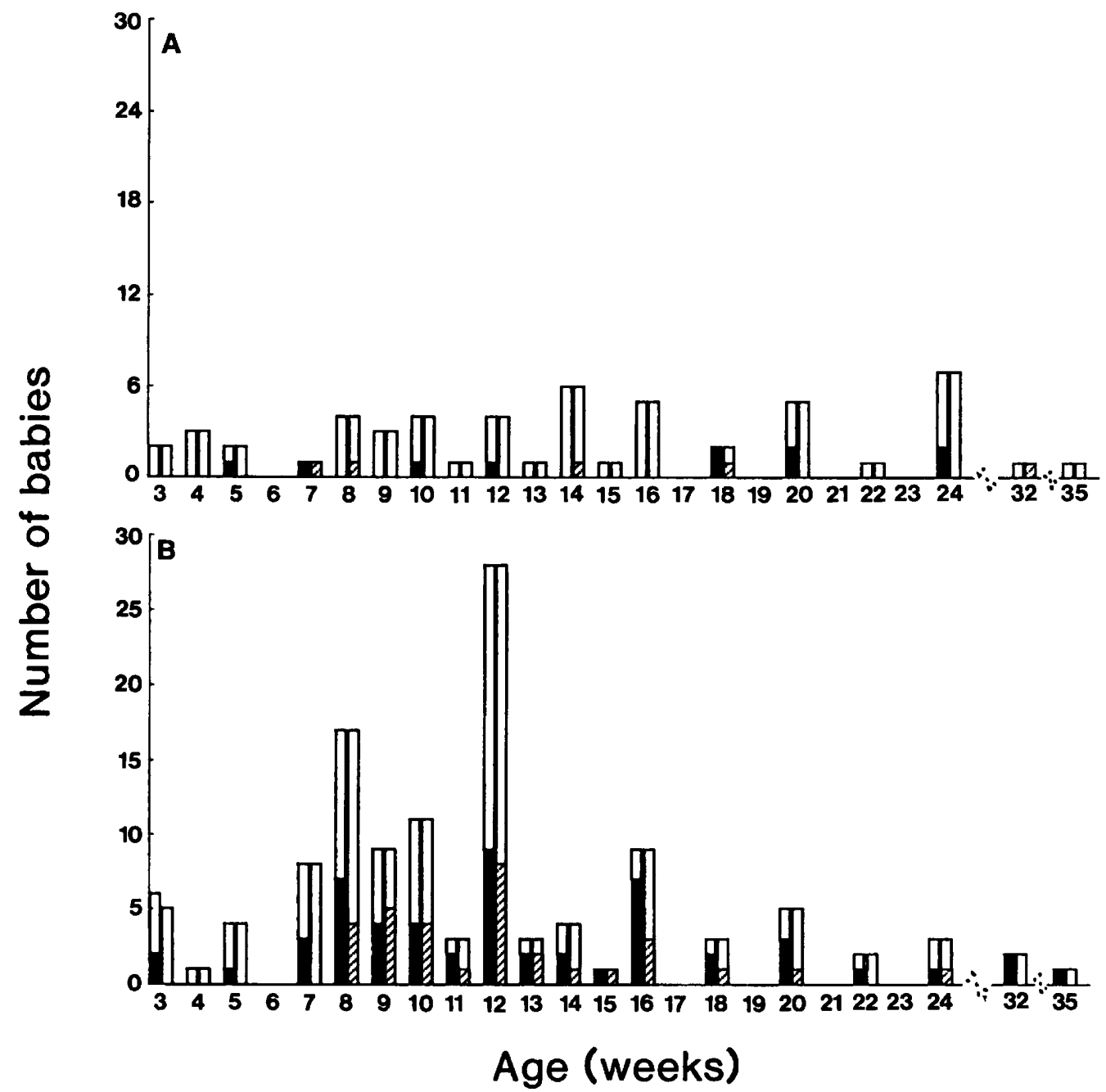

Fig. 1. Incidence of $C$. perfringens and HLML toxin in faecal samples of A, comparative group of babies, B, SIDS babies; $\square$, total babies tested at each age; $\square$, number of babies with $C$. perfringens; $\square$, number of babies with HLML toxin.

\section{Statistical analyses}

The significance of the equality of the two proportions for the SIDS group and the comparative group of babies was analysed by the $\chi^{2}$ test (table I). The association between the bacterial population and the presence of toxins was analysed for significance with a $\chi^{2}$ test for the homogeneity of proportions ${ }^{34}$ (tables II and III).

The samples, from both SIDS and healthy babies, from the two periods, were analysed to determine whether there were any significant differences between the results for age-matched babies from these periods. In most cases no significant difference was found so the results were pooled for analysis. When the results were different, the results for each period have been reported in the tables, even though the results in each period showed a similar trend.

\section{Results}

Incidence of $C$. perfringens and HLML toxin in faecal samples

The most common toxigenic bacterium present was
C. perfringens. It occurred in $45 \%$ of the faecal samples at counts $>\log _{10} 2 \cdot 48 / \mathrm{g}$ (fig. 1B, table I). The highest $\log _{10}$ count was $7.65 / \mathrm{g}$ and the mean of all samples was $4.92 / \mathrm{g}$. Most of the babies were aged $<20$ weeks at death and c. $50 \%$ of these contained numbers of $C$. perfringens as above. The viable counts of $C$. perfringens appeared to decline slightly after 20 weeks of age, and then increased in older babies, but this trend was not significant. There was no significant difference in the incidence of $C$. perfringens in babies $<12$ weeks and $\geqslant 12$ weeks of age, but in period $\mathrm{A}, 80 \%$, and period $\mathrm{B}, 86 \%$ of the positive babies were $\leqslant 16$ weeks old. There was a statistically significant relationship between the viable counts of $C$. perfringens and the presence of faecal HLML toxin $(\mathrm{p}<0.01)$ and $C$. perfringens enterotoxin in faeces $(\mathrm{p}<0.01)$ and serum samples $(\mathrm{p}<0.001)$ (table II).

The comparative group of babies at the time of sampling varied in age from 2 to 44 weeks. The babies were fairly randomly distributed in age (figs. $1 \mathrm{~A}$ and $2 \mathrm{~A})$. C. perfringens occurred in $20 \%$ of the babies with a maximum viable count of $\log _{10} 7 \cdot 48 / \mathrm{g}$ and a minimum of $3 \cdot 46 / \mathrm{g}$, mean $5 \cdot 38 / \mathrm{g}$ (fig. 1A, table I). The viable counts were slightly but not significantly higher in the 18-24-week age group. The incidence of $C$. 
Table I. Incidence of bacteria and toxins in faecal and serum samples from age-matched healthy and SIDS babies

\begin{tabular}{|c|c|c|c|c|c|c|c|}
\hline $\begin{array}{l}\text { Bacteria } \\
\text { or toxin }\end{array}$ & Babies & $\begin{array}{l}\text { Total } \\
\text { number of } \\
\text { babies } \\
\text { analysed }\end{array}$ & $\begin{array}{l}\text { Number } \\
\text { positive }\end{array}$ & $\begin{array}{c}\text { Percentage } \\
\text { positive }\end{array}$ & $\begin{array}{c}\text { Observed } \S \\
\chi^{2}\end{array}$ & $\begin{array}{l}\text { Range of } \\
\text { bacterial } \\
\text { counts } \\
\left(\log _{10} / g\right)\end{array}$ & $\begin{array}{c}\text { Mean } \\
\left(\log _{10} / g\right)\end{array}$ \\
\hline HLML toxin (faecal) & $\begin{array}{l}\text { Healthy } \\
\text { SIDS }\end{array}$ & $\begin{array}{r}47 \\
118\end{array}$ & $\begin{array}{r}5 \\
32\end{array}$ & $\begin{array}{l}11 \\
27\end{array}$ & $5 \cdot 24^{*}$ & $\begin{array}{l}\cdots \\
\cdots\end{array}$ & $\begin{array}{l}\cdots \\
\cdots\end{array}$ \\
\hline $\begin{array}{c}\text { C. perfringens } \\
\text { enterotoxin } \\
\text { serum }\end{array}$ & SIDS & 110 & 27 & 24 & & & \\
\hline faecal & $\begin{array}{l}\text { Healthy } \\
\text { SIDS }\end{array}$ & $\begin{array}{l}23 \\
96\end{array}$ & $\begin{array}{r}0 \\
33\end{array}$ & $\begin{array}{r}0 \\
34\end{array}$ & $10.94 \ddagger$ & $\begin{array}{l} \\
\cdots \\
\cdots\end{array}$ & $\begin{array}{l} \\
\cdots \\
\cdots\end{array}$ \\
\hline $\begin{array}{l}\text { bacteria } \\
\quad \text { Period A\| }\end{array}$ & $\begin{array}{l}\text { Healthy } \\
\text { SIDS }\end{array}$ & $\begin{array}{l}30 \\
77\end{array}$ & $\begin{array}{r}8 \\
40\end{array}$ & $\begin{array}{l}27 \\
52\end{array}$ & $\begin{array}{c}5 \cdot 58^{*} \\
\ldots\end{array}$ & $\begin{array}{l}\cdots \\
\cdots\end{array}$ & $\begin{array}{l}\cdots \\
\cdots\end{array}$ \\
\hline Period B & $\begin{array}{l}\text { Healthy } \\
\text { SIDS }\end{array}$ & $\begin{array}{l}21 \\
42\end{array}$ & $\begin{array}{r}2 \\
14\end{array}$ & $\begin{array}{l}10 \\
33\end{array}$ & $\begin{array}{c}4 \cdot 19^{*} \\
\ldots\end{array}$ & $\begin{array}{l}\ldots \\
\ldots\end{array}$ & $\begin{array}{l}\cdots \\
\cdots\end{array}$ \\
\hline Periods A and B & $\begin{array}{l}\text { Healthy } \\
\text { SIDS }\end{array}$ & $\begin{array}{r}51 \\
119\end{array}$ & $\begin{array}{l}10 \\
54\end{array}$ & $\begin{array}{l}20 \\
45\end{array}$ & $10 \cdot 10 \dagger$ & $\begin{array}{l}3 \cdot 46-7 \cdot 48 \\
2 \cdot 48-7 \cdot 65\end{array}$ & $\begin{array}{l}5 \cdot 38 \\
4 \cdot 92\end{array}$ \\
\hline $\begin{array}{l}\text { C. difficile } \\
\text { bacteria }\end{array}$ & $\begin{array}{l}\text { Healthy } \\
\text { SIDS }\end{array}$ & $\begin{array}{r}54 \\
119\end{array}$ & $\begin{array}{r}8 \\
33\end{array}$ & $\begin{array}{l}15 \\
28\end{array}$ & $3.43 \dagger \dagger$ & $\begin{array}{l}3 \cdot 24-7 \cdot 28 \\
2 \cdot 00-5 \cdot 68\end{array}$ & $\begin{array}{l}5 \cdot 18 \\
3 \cdot 96\end{array}$ \\
\hline $\begin{array}{l}\text { S. aureus } \\
\text { enterotoxin } \\
\text { serum }\end{array}$ & SIDS & 37 & 4 & 11 & $\ldots$ & $\ldots$ & $\ldots$ \\
\hline faecal & $\begin{array}{l}\text { Healthy } \\
\text { SIDS }\end{array}$ & $\begin{array}{l}19 \\
41\end{array}$ & $\begin{array}{l}0^{* *} \\
8\end{array}$ & $\begin{array}{r}0 \\
20\end{array}$ & $\begin{array}{c}4 \cdot 28^{*} \\
\ldots\end{array}$ & $\begin{array}{l}\ldots \\
\ldots\end{array}$ & $\begin{array}{l}\cdots \\
\cdots\end{array}$ \\
\hline bacteria & $\begin{array}{l}\text { Healthy } \\
\text { SIDS }\end{array}$ & $\begin{array}{l}14 \\
44\end{array}$ & $\begin{array}{l}12 \\
12\end{array}$ & $\begin{array}{l}86 \\
27\end{array}$ & $\begin{array}{r}14.9 \ddagger \\
\ldots\end{array}$ & $\begin{array}{l}3 \cdot 73-8 \cdot 28 \\
3 \cdot 22-8 \cdot 58\end{array}$ & $\begin{array}{l}5 \cdot 73 \\
4 \cdot 52\end{array}$ \\
\hline $\begin{array}{l}\text { C. botulinum } \\
\text { toxin }\end{array}$ & & & & & & & \\
\hline serum & $\begin{array}{l}\text { Healthy } \\
\text { SIDS }\end{array}$ & $\begin{array}{r}2 \\
120\end{array}$ & $\begin{array}{l}0 \\
0\end{array}$ & $\begin{array}{l}0 \\
0\end{array}$ & $\begin{array}{l}\cdots \\
\cdots\end{array}$ & $\begin{array}{l}\cdots \\
\cdots\end{array}$ & $\begin{array}{l}\cdots \\
\cdots\end{array}$ \\
\hline faecal & $\begin{array}{l}\text { Healthy } \\
\text { SIDS }\end{array}$ & $\begin{array}{r}49 \\
120\end{array}$ & $\begin{array}{l}0 \\
1\end{array}$ & $\begin{array}{l}0 \\
1\end{array}$ & $\begin{array}{l}\cdots \\
\cdots\end{array}$ & $\begin{array}{l}\cdots \\
\cdots\end{array}$ & $\begin{array}{l}\cdots \\
\cdots\end{array}$ \\
\hline bacteria & $\begin{array}{l}\text { Healthy } \\
\text { SIDS }\end{array}$ & $\begin{array}{r}53 \\
120\end{array}$ & $\begin{array}{l}0^{* *} \\
6\end{array}$ & $\begin{array}{l}0 \\
5\end{array}$ & $\begin{array}{c}2 \cdot 74 \dagger \dagger \\
\ldots\end{array}$ & $\begin{array}{l}\cdots \\
\cdots\end{array}$ & $\begin{array}{l}\ldots \\
\cdots\end{array}$ \\
\hline $\begin{array}{l}\text { HeLa cell cytotoxicity } \\
\text { cytotoxin } \\
\text { serum }\end{array}$ & SIDS & 87 & 24 & 28 & $\ldots$ & $\ldots$ & $\ldots$ \\
\hline faecal & $\begin{array}{l}\text { Healthy } \\
\text { SIDS }\end{array}$ & $\begin{array}{r}21 \\
123\end{array}$ & $\begin{array}{l}0^{* *} \\
38\end{array}$ & $\begin{array}{r}0 \\
31\end{array}$ & $\begin{array}{r}8 \cdot 8 \dagger \\
\ldots\end{array}$ & $\begin{array}{l}\cdots \\
\cdots\end{array}$ & $\begin{array}{l}\cdots \\
\cdots\end{array}$ \\
\hline $\begin{array}{l}\text { C. perfringens } \\
\alpha \text {-toxin } \\
\text { (presumptive) } \\
\text { serum }\end{array}$ & SIDS & 87 & 2 & 2 & $\ldots$ & $\ldots$ & $\ldots$ \\
\hline faecal & $\begin{array}{l}\text { Healthy } \\
\text { SIDS }\end{array}$ & $\begin{array}{l}17 \\
80\end{array}$ & $\begin{array}{l}0^{* *} \\
14\end{array}$ & $\begin{array}{r}0 \\
18\end{array}$ & $\begin{array}{c}3 \cdot 5 \dagger \dagger \\
\ldots\end{array}$ & $\begin{array}{l}\cdots \\
\cdots\end{array}$ & $\begin{array}{l}\cdots \\
\cdots\end{array}$ \\
\hline
\end{tabular}

* Significant at $\mathrm{p}=0.05$ level.

+ Significant at $\mathrm{p}=0.01$ level.

Significant at $\mathrm{p}=0.001$ level.

$\S$ Statistical test for equality of 2 proportions with 1 degree of freedom.

$\|$ Unless Period A or B is specified, there was no period effect, and the data from Period A and B were pooled for the $\chi^{2}$ analysis.

** Figures of zero incidence make the $\chi^{2}$ estimations approximate only.

†† $\chi^{2}$ of 3.8 required for significance at the $\mathrm{p}=0.05$ level.

perfringens in the comparative group of babies $\leqslant 12$ weeks was 4 of 22 and > 12 weeks was 6 of 29 .

Incidence of $C$. difficile and HLML toxin in faecal samples

C. difficile occurred in $28 \%$ of SIDS samples at a viable count $>10^{2} / \mathrm{g}$. The highest count was $\log _{10}$
$5 \cdot 68 / \mathrm{g}$, and the mean count was $\log _{10} 3.96 / \mathrm{g}$ (fig. 2, table I). C. difficile occurred mostly in SIDS babies < 16 weeks old at death $(91 \%$ of the positive samples, $90 \%$ period A, $91 \%$ period B). About $25 \%$ of the faecal samples contained $C$. difficile (fig. 2B). Fig. 2 shows the close association between the presence of this bacterium and faecal HLML toxin.

However, the relationship between the viable counts 
Table II. The association between the number of $C$. perfringens bacteria in SIDS faecal samples and the presence of HLML toxin in faeces and of $C$. perfringens enterotoxin in faeces and serum of SIDS babies

\begin{tabular}{|c|c|c|c|}
\hline \multirow{2}{*}{ Group } & \multirow{2}{*}{$\begin{array}{c}\text { Faecal } \\
\text { bacterial } \\
\text { levels }\left(\log _{10} / g\right)\end{array}$} & Toxin & \multirow{2}{*}{$\begin{array}{l}\text { Percentage } \\
\text { positive }\end{array}$} \\
\hline & & Positive Negative & \\
\hline
\end{tabular}

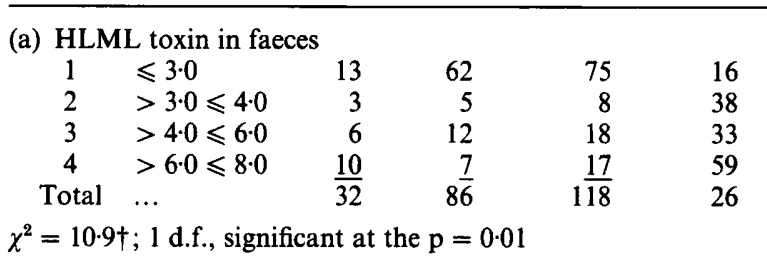

\begin{tabular}{|c|c|c|c|c|c|c|}
\hline \multicolumn{7}{|c|}{$\begin{array}{l}\text { (b) Enterotoxin* in faeces } \\
\text { Period A }\end{array}$} \\
\hline 1 & $\leqslant 3 \cdot 0$ & 9 & 18 & & 27 & 33 \\
\hline 2 & $>3 \cdot 0 \leqslant 4 \cdot 0$ & 1) & 6) & & 7 & 14 \\
\hline 3 & $>4 \cdot 0 \leqslant 6.0$ & $4\} 12$ & $5\}$ & 14 & 9 & 44 \\
\hline 4 & $>6.0 \leqslant 8.0$ & $7)$ & $3)$ & & 10 & 70 \\
\hline \multicolumn{7}{|c|}{$\chi^{2}=0.91 \dagger$, not significant } \\
\hline \multicolumn{7}{|c|}{ Period B } \\
\hline 1 & $\leqslant 3 \cdot 0$ & 0 & 28 & & 28 & 0 \\
\hline 2 & $>3 \cdot 0 \leqslant 4.0$ & $0)$ & $0)$ & & 0 & 0 \\
\hline 3 & $>4 \cdot 0 \leqslant 6.0$ & $6\} 11$ & 3 & 3 & 9 & 67 \\
\hline 4 & $>6.0 \leqslant 8.0$ & $5 \mathrm{~J}$ & $0 \mathrm{~J}$ & & 5 & 100 \\
\hline
\end{tabular}

$\chi^{2}=29.8 \dagger$, significant at $\mathrm{p}=0.001$ level

Pooled $A+B \chi^{2}=17.5+$, significant at $p=0.01$

(c) Enterotoxin* in sera

$\begin{array}{llrrrr}1 & \leqslant 3 \cdot 0 & 9 & 58 & 67 & 13 \\ 2 & >3 \cdot 0 \leqslant 4 \cdot 0 & 3 & 4 & 7 & 43 \\ 3 & >4 \cdot 0 \leqslant 6 \cdot 0 & 9 & 9 & 18 & 50 \\ 4 & >6.0 \leqslant 8 \cdot 0 & \frac{6}{7} & \frac{10}{81} & 1 \frac{16}{108} & 38\end{array}$

$\chi^{2}=12 \cdot 6 ; 1$ d.f., significant at $p=0.001$

* The RPLA test for $C$. perfringens enterotoxin is specific and sensitive, detecting $2 \mathrm{ng}$ of toxin/ml. At lower concentrations this could lead to positive or negative test, but it was presumed positive when some agglutination was observed.

$\dagger \chi^{2}$ calculated from pooled values $>3.0$ versus $<3.0$.

of $C$. difficile and the presence of HLML toxin in faecal samples was not quite significant (table III). Twenty faecal samples contained both $C$. perfringens and C. difficile.

C. difficile occurred in $15 \%$ of the comparative babies with a maximum viable count of $\log _{10} 7 \cdot 28 / \mathrm{g}$ and a minimum of $3 \cdot 24 / \mathrm{g}$, mean $5 \cdot 18 / \mathrm{g}$ (fig. $2 \mathrm{~A}$, table I).

\section{Incidence of other enterotoxigenic bacteria in faecal samples}

The observations on $S$. aureus were made only on babies in period B. $S$. aureus (coagulase positive) was present in $27 \%$ of SIDS samples; the highest count was $\log _{10} 8 \cdot 58 / \mathrm{g}$ and the mean count $\log _{10} 4 \cdot 52 / \mathrm{g}$ (table I). C. jejuni, Y. enterocolitica, $V$. parahaemolyticus, salmonellae, $\beta$-haemolytic streptococci, $A$. hydrophila and $B$. cereus were not detected, respectively, in 55,34 , $63,65,19,19$ and 101 SIDS faecal samples examined. C. botulinum type A or B was detected in six samples but in only low most probable numbers- $13 / \mathrm{g}$ in sample 43 (type B), 46/g in sample 97 (type B) and $1 \cdot 2 / \mathrm{g}$ in sample 98 (type A). C. botulinum toxin was not detected in the serum samples but was present in only one faecal sample-sample 73 (type A at $12 \mathrm{LD} 50 / \mathrm{g}$ ).

HLML toxin was detected in SIDS sample 106 but the number of $C$. botulinum was not determined and its toxin, although neutralised by polyvalent $C$. botulinum antiserum, was not typed. This faecal sample also contained $S$. aureus and $C$. perfringens, and both their toxins were present in the faeces and serum of this baby.

C. botulinum, $Y$. enterocolitica or $A$. hydrophila were not detected in 53, 48 and 27 samples, respectively, from the comparative group of babies. Two of 50 samples contained Salmonella spp. and one of 25 contained $B$. cereus. $\beta$-Haemolytic streptococci were detected in 1 of 25 samples. $S$. aureus occurred in $86 \%$ of faecal samples from healthy babies in numbers up to $\log _{10} 8 \cdot 28 / \mathrm{g}$ (mean $5 \cdot 73 / \mathrm{g}$; table I).

\section{HLML toxin in faecal extracts}

Many of the extracts from the faecal samples containing $C$. perfringens and $C$. difficile were lethal to mice, particularly those from the SIDS babies in the 9-16-week age group (figs. 1B and 2B). Faecal extracts from $27 \%$ of SIDS cases contained HLML toxin (table I); $19(59 \%)$ of these SIDS samples contained significant populations of $C$. perfringens (fig. 1B) and $11(31 \%)$ contained $C$. difficile (fig. 2B). Nine of the toxins of $C$. perfringens, plus its enterotoxin, and the two $C$. difficile toxins were lethal to mice and heatlabile. Seven toxic SIDS samples contained both $C$. perfringens and $C$. difficile. Two samples contained HLML toxin but not $C$. perfringens, $C$. difficile or other food-poisoning bacteria. Sixteen SIDS faecal samples contained $C$. perfringens, six contained $C$. difficile and 11 contained both, but the faecal extracts were not toxic to mice.

Only $11 \%$ of the faecal samples from the comparative babies contained HLML toxin and only two of these contained significant numbers of $C$. perfringens. One of these samples contained $\log _{10} 6 \cdot 9 / \mathrm{g}$ of $E$. coli which, when subcultured, produced a culture supernate containing HLML toxin.

\section{Enterotoxins in faecal and serum samples}

SIDS babies. The results of the reverse passive latex agglutination tests for $C$. perfringens enterotoxin in SIDS faecal extracts and sera are given in fig. 3 . The figure shows a close association between the presence of the toxin in the faeces and serum. The relationship between the viable counts of $C$. perfringens and the presence of the enterotoxin was highly significant (table II). Thirty-four percent of faecal extracts and $24 \%$ of serum samples analysed gave positive results for $C$. perfringens enterotoxin. Twelve SIDS infants had $C$. perfringens in their faeces, and gave positive results in tests for enterotoxin in both faeces and 


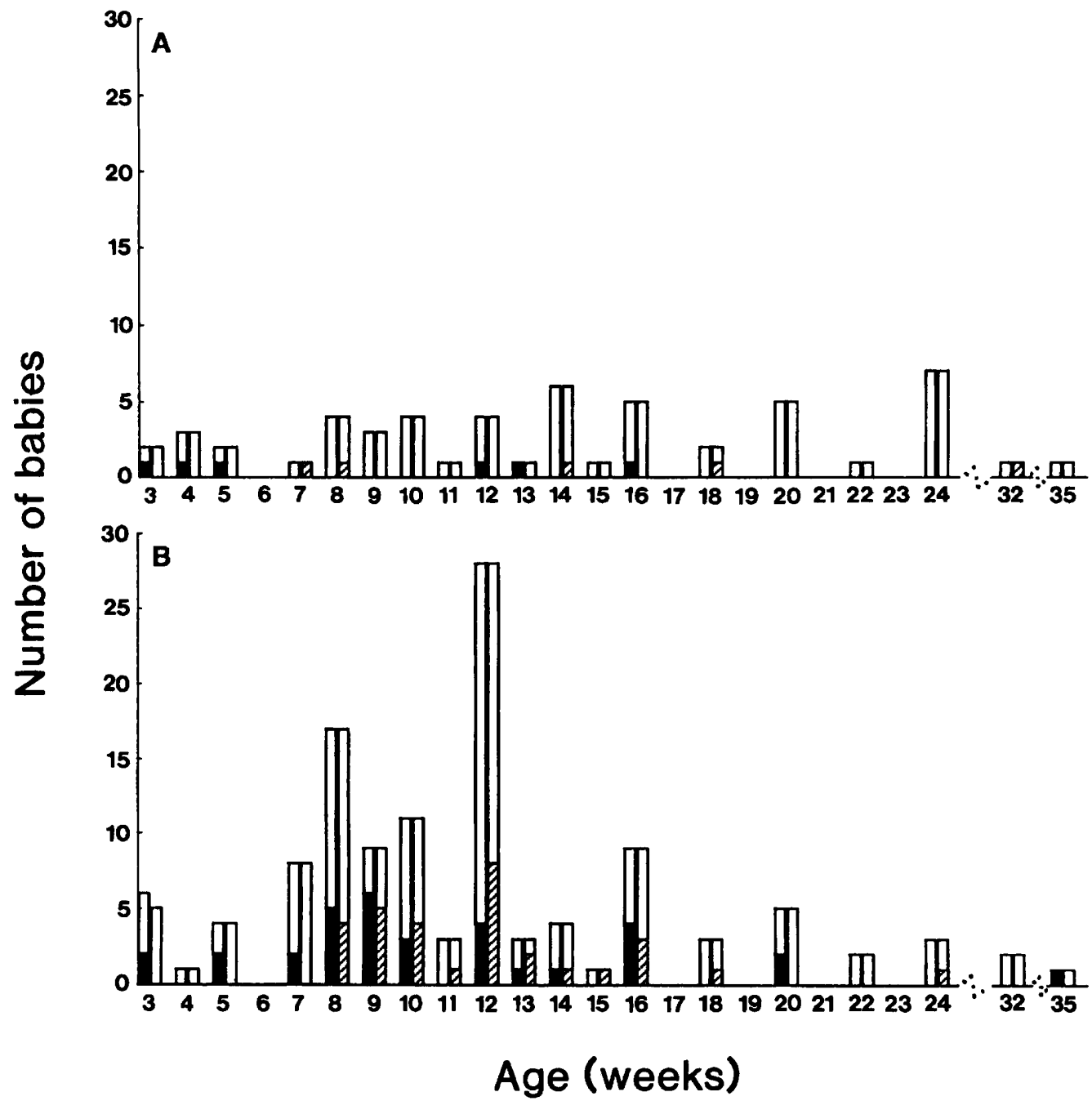

Fig. 2. Incidence of $C$. difficile and HLML toxin in faecal samples of $\mathbf{A}$, the comparative group of babies $\mathbf{B}$, SIDS babies; $\square$, total babies tested at each age; $\mathbf{D}$, number of babies with $C$. difficile; $\square$, number of babies with HLML toxin.

Table III. Relationship between the number of $C$. difficile bacteria in SIDS faecal samples and the presence of HLML toxin in faeces

\begin{tabular}{cccc}
\hline & $\begin{array}{c}\text { Faecal } \\
\text { bacterial } \\
\text { levels } \\
\left(\log _{\mathbf{1 0}} / \mathrm{g}\right)\end{array}$ & Positive Negative & Toxin \\
samples & $\begin{array}{c}\text { Percentage } \\
\text { positive }\end{array}$ \\
\hline
\end{tabular}

(a) HLML toxin in faeces

Period A

$\begin{array}{rrrrr}\leqslant 3 \cdot 0 & 12 & 51 & 63 & 19 \\ >3 \cdot 0 & 4 & 9 & 13 & 31\end{array}$

Period B

$\begin{array}{rrrrr}\leqslant 3 \cdot 0 & 10 & 20 & 30 & 33 \\ >3.0 & 6 & 5 & 11 & 54\end{array}$

Pooled A+B $\chi^{2}=3 \cdot 1$, not significant

The proportion of positive to negative samples was different in the two time periods, even though the percentage positive rate was higher when the viable count was higher in each period.

serum. Twenty-four ( $44 \%)$ of the 54 faecal samples that contained $C$. perfringens contained enterotoxin. In $23(42 \%)$ of the 54 infants whose faecal samples contained $C$. perfringens the serum sample gave posi- tive results in tests for enterotoxin. Staphylococcal enterotoxin was detected in 4 of 37 serum samples and was in 8 of 41 faecal extracts (table I).

A small number of samples was tested for HeLa cell cytotoxicity, ${ }^{23}$ neutralisable by $C$. sordellii antiserum. Of 12 positive faecal samples tested, eight were cytotoxic but this activity was not neutralised by $C$. sordellii antiserum, and seven of these contained $C$. perfringens enterotoxin. Three SIDS serum samples were also cytotoxic but again these samples gave positive results in tests for $C$. perfringens enterotoxin. Of four SIDS faecal samples cytotoxic to HeLa cells, the toxicity was neutralised by $C$. sordellii antiserum. Two SIDS serum samples were also HeLa cell cytotoxic with results that indicated the presence of $C$. difficile toxin. $C$. difficile toxin was confirmed in four faecal and two serum samples by ELISA.

Samples from six near-miss SIDS cases were analysed. Faecal samples from two of the cases contained HLML toxin and $C$. perfringens, and one of them contained $C$. difficile also. A sample from one other case contained $C$. difficile alone. $C$. botulinum toxin was not detected in the faecal extracts of any of these samples. Serum samples were not tested. 


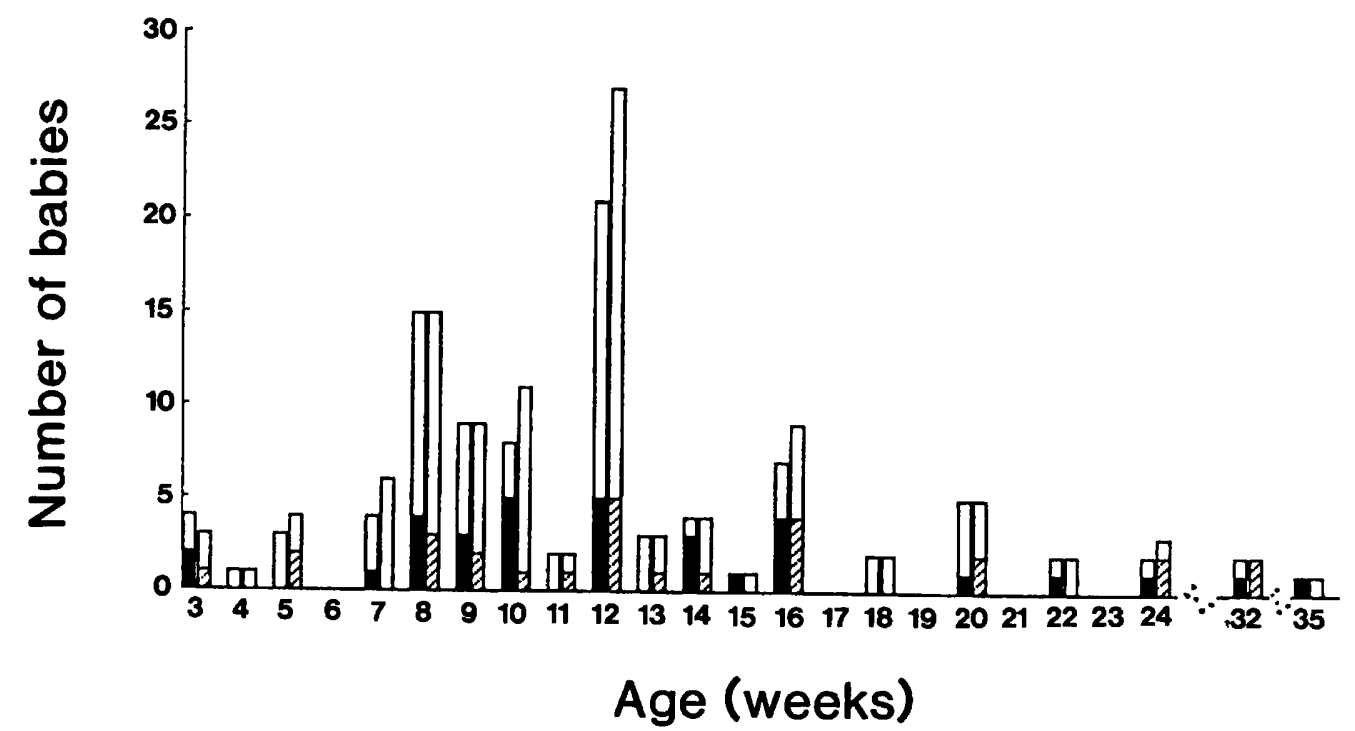

Fig. 3. Incidence of $C$. perfringens enterotoxin in faecal extracts and serum of SIDS babies according to age at death. $\square$, total babies tested;

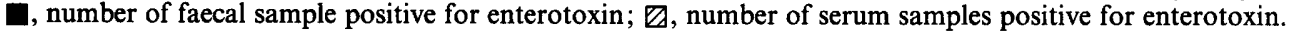

Table IV. Incidence of bacterial toxins in the SIDS samples cytotoxic to HeLa cells

\begin{tabular}{lcc}
\hline \multirow{2}{*}{ Toxin } & \multicolumn{2}{c}{ Number of positive samples } \\
\cline { 2 - 3 } & Faeces (123) & Serum (87) \\
\hline Cytotoxin & 38 & 24 \\
HLML & 13 & 6 \\
C. perfringens enterotoxin & 13 & 6 \\
C. perfringens $\alpha$-toxin & 14 & 2 \\
C. difficile (HeLa cell toxin) & $\ldots$ & $1^{*}$ \\
\hline
\end{tabular}

* Out of six samples tested.

Healthy babies. None of the faecal extracts from these babies gave a positive result in tests for enterotoxins of $C$. perfringens or staphylococci by the slide RPLA (table I).

\section{Cytotoxins and C. perfringens $\alpha$-toxin (phospholipase, lecithinase)}

Thirty-one percent of the faecal extracts tested and $28 \%$ of the serum samples from the SIDS babies were cytotoxic to HeLa cells but the toxicity was not neutralised by $C$. sordellii antiserum (tables I and IV). Antiserum to $C$. perfringens enterotoxin was not available for testing. The HeLa cells showed rounding up into much larger spheres than those pictured by Rolfe, ${ }^{23}$ and the cells were often ruptured releasing large clumps of granular cytoplasm. This effect was reproduced by a high concentration $(5 \mu \mathrm{g} /$ well) of purified $C$. perfringens $\alpha$-toxin (Sigma). Many of the cytotoxic samples were neutralised by $C$. perfringens type A diagnostic serum. With this cytotoxicity test for $C$. perfringens $\alpha$-toxin, it was detected presumptively in 14 of 80 faecal samples and 2 of 87 serum samples from SIDS babies (table I).

No HeLa cell cytotoxicity was detected in 21 , or $C$. perfringens $\alpha$-toxin in 17 , faecal samples from healthy babies (table I).
Effects of other factors on the incidence of enteric pathogens and their enterotoxins

Various factors, including feeding pattern, sex of baby, season of death and position at death (sleeping position), appear to affect the incidence of SIDS. Since it was not possible to make age-matched comparisons of statistically significant samples of these categories without undertaking bacteriological analyses of many more babies, a comparison of the effect of these factors without consideration of age and other matching subcategories was performed (tables V and VI). Formulafed SIDS babies had a significantly higher incidence of $C$. difficile, $C$. perfringens and its enterotoxin in their faeces than did breast-fed babies. Formula-fed SIDS babies also had a higher incidence of $C$. perfringens enterotoxin in serum and faecal HLML toxin, $S$. aureus and staphylococcal enterotoxin than breast-fed babies, but not significantly so (table Va). Male SIDS babies had a significantly higher incidence of $C$. perfringens than female babies but a non-significantly higher incidence of $C$. perfringens enterotoxin, HLML toxin, $C$. difficile and $S$. aureus and its enterotoxins (table Vb). SIDS babies dying in winter had a significantly higher incidence of $C$. difficile than those dying in summer and spring (table $\mathrm{Vc}$ ). The other bacteria and their enterotoxins, except $C$. perfringens enterotoxin, occurred in a higher percentage of babies dying in autumn and winter than in spring and summer but not significantly so.

The incidence of these pathogens and their toxins in the comparative babies was too low to draw any reliable conclusions in relation to the effect of these epidemiological influences (table V).

The incidence of the enteric pathogens or their toxins did not differ in relation to the position of the baby at death (table VI).

\section{Significance of the bacterial and toxin results}

Table I summarises the results of the bacterial viable 
Table V. Effect of (a) feeding pattern, (b) sex and (c) season of death or sampling season on the incidence of enteric pathogens in faecal samples and their toxins in faecal and serum samples from SIDS babies and faecal samples from the comparative group of babies

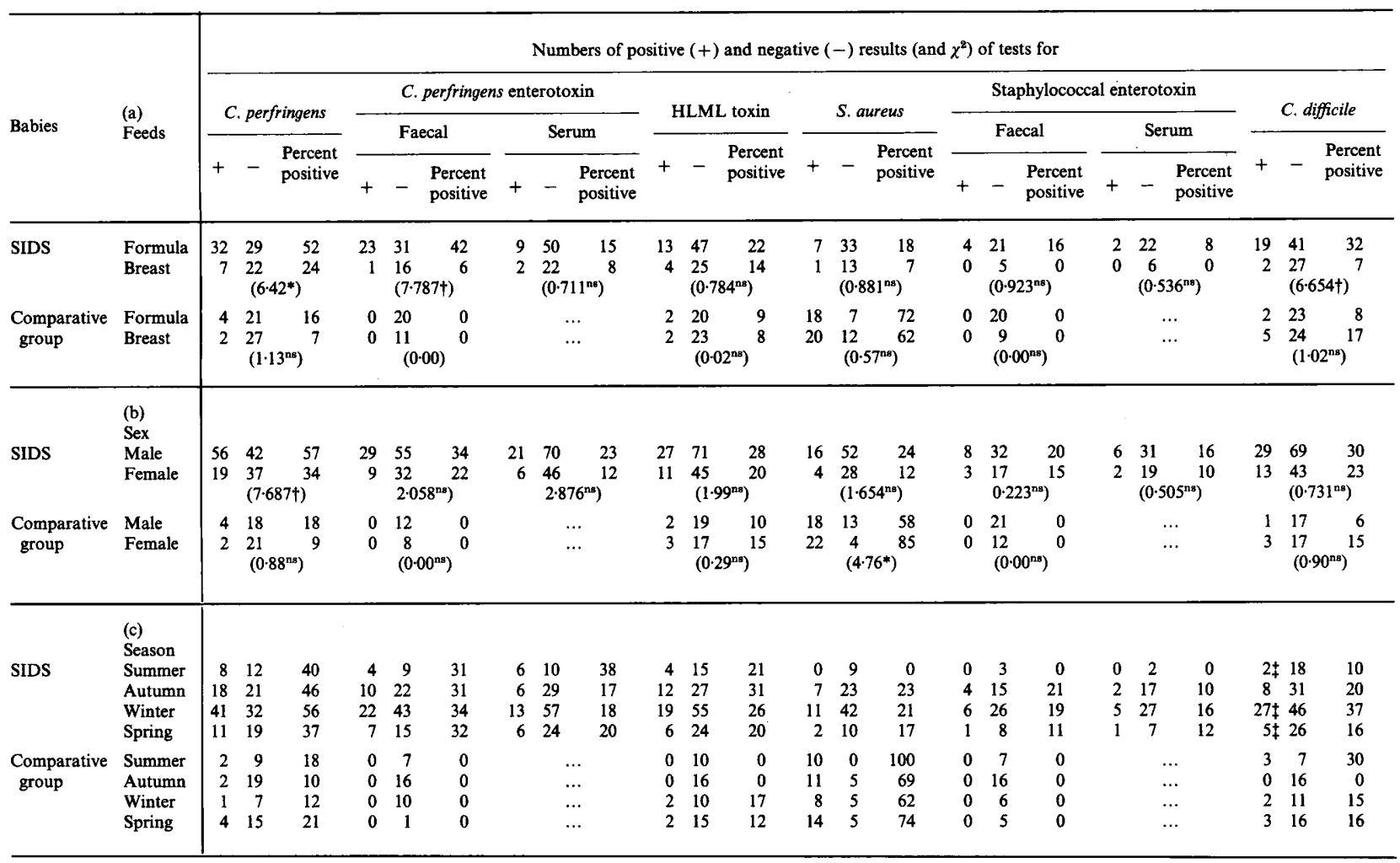

* Significant at $\mathrm{p}=0.05$; † significant at $\mathrm{p}=0.01$; ns, not significant.

$\ddagger$ For $C$. difficile $\chi^{2}$ for SIDS incidence winter $v$ s summer $(5 \cdot 328)$ and winter $v s$ spring $(4 \cdot 444)$ were significant at $\mathrm{p}=0 \cdot 05$. All other comparisons were not significant.

Table VI. Incidence of enteric pathogens and their toxins in SIDS babies according to position at death

\begin{tabular}{|c|c|c|c|c|c|c|c|}
\hline \multirow{2}{*}{$\begin{array}{l}\text { Pathogen } \\
\text { or } \\
\text { toxin }\end{array}$} & \multicolumn{3}{|c|}{ Prone* } & \multicolumn{3}{|c|}{ Other† } & \multirow[b]{2}{*}{$\chi^{2}$} \\
\hline & $\begin{array}{c}\text { Number } \\
\text { of } \\
\text { babies }\end{array}$ & $\begin{array}{l}\text { Number } \\
\text { of positive } \\
\text { samples }\end{array}$ & $\begin{array}{l}\text { Percent } \\
\text { positive }\end{array}$ & $\begin{array}{c}\text { Number } \\
\text { of } \\
\text { babies }\end{array}$ & $\begin{array}{l}\text { Number } \\
\text { of positive } \\
\text { samples }\end{array}$ & $\begin{array}{l}\text { Percent } \\
\text { positive }\end{array}$ & \\
\hline HLML toxin & 63 & 14 & 22 & 100 & 28 & 28 & 0.675 \\
\hline C. perfringens & 63 & 28 & 44 & 100 & 51 & 51 & 0.665 \\
\hline $\begin{array}{l}\text { C. perfringens } \\
\text { enterotoxin } \\
\text { faecal } \\
\text { serum }\end{array}$ & $\begin{array}{l}52 \\
59\end{array}$ & $\begin{array}{l}16 \\
13\end{array}$ & $\begin{array}{l}31 \\
22\end{array}$ & $\begin{array}{l}82 \\
93\end{array}$ & $\begin{array}{l}27 \\
17\end{array}$ & $\begin{array}{l}33 \\
18\end{array}$ & $\begin{array}{l}0.068 \\
0.321\end{array}$ \\
\hline $\begin{array}{l}\text { C. difficile } \\
\text { S. aureus }\end{array}$ & $\begin{array}{l}63 \\
41\end{array}$ & $\begin{array}{r}18 \\
8\end{array}$ & $\begin{array}{l}28 \\
20\end{array}$ & $\begin{array}{r}100 \\
64\end{array}$ & $\begin{array}{l}24 \\
11\end{array}$ & $\begin{array}{l}24 \\
17\end{array}$ & $\begin{array}{l}0.422 \\
0.091\end{array}$ \\
\hline $\begin{array}{l}\text { Staphylococcal } \\
\text { enterotoxin } \\
\text { faecal } \\
\text { serum }\end{array}$ & $\begin{array}{l}24 \\
22\end{array}$ & $\begin{array}{l}5 \\
0\end{array}$ & $\begin{array}{r}21 \\
0\end{array}$ & $\begin{array}{l}39 \\
39\end{array}$ & $\begin{array}{l}6 \\
8\end{array}$ & $\begin{array}{l}15 \\
20\end{array}$ & $\begin{array}{l}0.306 \\
5.1948\end{array}$ \\
\hline
\end{tabular}

* Recorded in coroners', police and autopsy reports as found in prone position.

$\dagger$ In most cases position other than prone was not recorded so data may include some unreported prone cases.

$\S$ Significant at $p=0.05$.

counts and toxin analyses of the samples from the SIDS and healthy babies. They were analysed for the significance of the equality of the two proportions by the $\chi^{2}$ test with 1 degree of freedom. Four of the nine comparisons- $C$. perfringens, its enterotoxin, cytotoxins and coagulase-positive staphylococciwere significantly different at $p \leqslant 0.01$, and the HLML toxin at $\mathrm{p}=0.05$. The $C$. difficile, $C$. botulinum 
and $C$. perfringens $\alpha$-toxin comparisons were almost significant.

\section{Persistence of $C$. perfringens and $C$. difficile and their toxins in faecal samples from healthy babies}

Since faeces from some of the healthy babies contained HLML toxin and toxigenic bacteria, it was of interest to see whether this situation was stable or changed with time. The viable counts of $C$. perfringens and the presence of HLML toxin were followed over periods of 2 and 5 months in two babies. There was no significant change in the viable count of $C$. perfringens and in only 3 of 12 samples was HLML toxin detected. In one of these, and a third baby, consecutive weekly samples were HLML toxin-positive.

\section{Toxigenicity of isolates of $C$. perfringens from faecal samples of SIDS babies}

Some SIDS samples contained these toxigenic bacteria but the faecal samples were HLML toxinnegative. Therefore, some preliminary tests were made of the toxigenicity of the isolates. Five HLML toxinnegative faecal samples gave toxigenic subcultures. Three other faecal samples containing these bacteria were HLML toxin-negative and remained so on subculture, whereas only four of six HLML toxinpositive samples were toxic on subculture. These results suggest that weakly or non-toxigenic strains occur, and, also, that in some babies the conditions may not be suitable for toxin production or there has been inactivation of toxin.

\section{Discussion}

Most previous studies have relied on enrichment techniques to detect bacteria. However, our results show that many SIDS faecal specimens contain significant numbers of enterotoxigenic bacteria on primary culture and that their toxins occur in both the faeces and serum of these babies. Various sampling and handling problems should be considered before assessing the significance of these findings. The most important are probably the temperature of the intestinal contents prior to autopsy and changes that may take place during storage before bacteriological analysis, e.g., some bacterial growth and toxin production may occur post mortem. However, this is not believed to be a major problem, because being small and having a large surface area to weight ratio, infants cool fairly quickly in non-air-conditioned homes and are then held at refrigeration temperature in the mortuary until autopsy. Refrigeration prevents toxin formation and the growth of pathogens other than $Y$. enterocolitica, but does not prevent the death of mesophiles due to chilling or the enzymic inactivation of toxin. The optimum temperature for growth of most pathogenic bacteria is $c .37^{\circ} \mathrm{C}\left(45^{\circ} \mathrm{C}\right.$ for $C$. perfringens). Growth slows rapidly below these tem- peratures and there is virtually no growth of or toxin production below $15^{\circ} \mathrm{C}$ by $C$. perfringens. ${ }^{35-37} \mathrm{C}$. difficile has been reported to grow at $25-45^{\circ} \mathrm{C} .3^{38}$ Preliminary studies on the growth of $C$. difficile and $S$. aureus in stool samples at various temperatures suggest that the conditions are not favourable for growth and toxin production. The presence of toxins in the serum of SIDS babies also indicates formation and absorption of toxins before or at the time of death.

Although in this study an accurate quantification of the number of enterotoxigenic bacteria is of little significance, the number of bacteria above a certain level is a much better indication of colonisation than that deduced from enrichment cultures. Hence, enrichment media (except for $C$. botulinum) were not used to detect low numbers of bacteria, and no effort was made to resuscitate bacteria damaged by chilling or storage. Therefore, most of the bacterial counts are likely to be underestimates. A check on the loss in viability of bacteria in fresh stools stored at $1-2^{\circ} \mathrm{C}$ in BioBags for a few days showed that most of the bacteria in the normal faecal flora retained their viability well in faeces (unpublished observations). C. difficile survives for $4-10$ days at $5^{\circ} \mathrm{C} .{ }^{39}$ However, $C$. perfringens readily suffers cold damage and considerable loss of viability at $0-5^{\circ} \mathrm{C} .^{40}$

The toxin detection methods used were unlikely to be $100 \%$ effective, and the amount of toxin present was not determined. More sensitive, commercial, monoclonal antibody-ELISA methods were not available at the start of these studies. The latex agglutination methods used, that have become available, except for that of $C$. difficile toxin A, are reasonably sensitive and specific. ${ }^{41,42}$ In the absence of a satisfactory RPLA test for $C$. difficile toxins, many of the samples were tested for cytotoxicity; although they often showed cytotoxicity, this was not neutralised by the $C$. sordellii antisera, indicating that it was probably due to toxins of $C$. perfringens or other bacterial species. However, a few SIDS faecal extracts and serum samples did show evidence of the $C$. difficile toxins.

Most toxins are inactivated to some extent during storage. $C$. difficile cytotoxin is fairly stable at $0^{\circ} \mathrm{C}$, but its activity falls to $c .3 \%$ in 2 days at $5^{\circ} \mathrm{C} .{ }^{39}$ The HLML toxin and $C$. perfringens enterotoxin in faeces and faecal extracts both lost considerable activity in 2-3 days at $1^{\circ} \mathrm{C}$ (unpublished observations). The effectiveness of the toxin-extraction methods was not explored. Both effectiveness of toxin-extraction and loss of activity are likely to result in an underestimation of the incidence of toxin in the faecal samples.

The failure to detect toxin in many of the faecal samples and sera when the toxigenic bacteria were found in the stools of SIDS and healthy babies may result from the frequently observed occurrence of nontoxigenic strains of $C$. perfringens, ${ }^{43-46} C$. difficile, ${ }^{6,47,48}$ enterotoxigenic $E$. coli and other species. Nontoxigenic isolates were also observed in this study. The absence of toxin may have also resulted from unfavourable conditions for toxin production in the 
intestinal tract of some babies, due to their diet or from immunological factors. In five SIDS faecal samples, toxins of $C$. perfringens or $C$. difficile were demonstrated but the bacteria were not detected. Presumably, this resulted from death of the bacteria during storage or from cold damage.

Staphylococcal enterotoxin occurred in some of the SIDS faecal and serum samples. C. perfringens and $C$. difficile were also present in many of these faecal samples. However, in one case, HLML toxin was present in the absence of $C$. perfringens and $C$. difficile, suggesting that $S$. aureus enterotoxin may be important under conditions where the strain is toxigenic and sufficient toxin is produced. Of considerable interest is the finding that $S$. aureus occurred significantly more frequently in the comparative group of babies in the absence of toxin, whereas when they were present in the SIDS samples toxin was normally present (table I). The HeLa cell cytotoxicity observed could result from $C$. difficile toxin A and its cytotoxin, $C$. perfringens enterotoxin and $\alpha$-toxin and possibly other toxins and the presence of two or more of these in the one sample (table IV).

The results show that, in a higher percentage of SIDS cases, there are toxins (the HLML toxin, $C$. botulinum toxin and the enterotoxins of $C$. perfringens, $C$. difficile and $S$. aureus, and the $\alpha$-toxin of $C$. perfringens) in faecal samples and, in the case of the latter four, in serum. The failure of extracts from some faecal samples containing $C$. perfringens and $C$. difficile to be lethal for mice is also likely to result from insufficient toxin rather than the reasons suggested above.

The RPLA test detects $C$. perfringens enterotoxin at $2 \mathrm{ng} / \mathrm{ml}$ whereas the LD50 for mice is $c .0 .8 \mu \mathrm{g}^{49}$ Insufficient toxin probably results from loss of toxin activity during storage of samples. Over one-third of the extracts contained detectable toxin by RPLA.

Although C. botulinum occurred in six of the 123 SIDS cases, an incidence similar to that found in California, ${ }^{1}$ the number of bacteria of this species present was low and its toxin was detected in only one faecal sample. This situation is more typical of the late recovery phase of infant botulism than of an acute attack. ${ }^{50}$ Thus, the true significance of the presence of C. botulinum is not known. Most cases of infant botulism in Australia have occurred in relatively arid country areas, ${ }^{22}$ so the incidence for these samples from metropolitan areas should not be applied to the national scene.

Altogether, 77 of the 123 SIDS samples (62\%) contained one of the above toxigenic bacteria or their toxins or both, and, as indicated earlier, these findings could be an underestimate. A significantly lower incidence of these bacteria and their toxins occurred in the healthy babies (figs. 1 and 2; table I). Tests were not done for other toxigenic bacteria, such as $A$. hydrophila, Listeria monocytogenes and enterotoxigenic E. coli.

The important question is, are these bacteria and their toxins involved in the death of these babies? There are several published reports on the occurrence of $C$. perfringens and $C$. difficile in stools from babies of different age, ${ }^{51}$ and diet, ${ }^{51,52}$ hospitalised with diarrhoea $^{53,54}$ and on death (SIDS cases) ${ }^{52,55}$ and the question has been raised as to whether these bacteria have any significant effect on the health of the baby. Toxin analyses have been performed in only a few previous studies. $C$. difficile toxin was found in the faeces of SIDS cases and healthy babies ${ }^{6,52-55}$ but not in their serum. ${ }^{52} C$. perfringens toxin was detected by a very sensitive method in faecal and serum samples at about the same frequency in some SIDS and dead nonSIDS cases. ${ }^{7}$ The degree of toxicity and incidence of non-toxigenic strains is important, as are the facts that $C$. perfringens is responsible for the death of several species of young animals ${ }^{7}$ and $C$. difficile causes pseudomembraneous colitis. $C$. difficile toxins also have been shown to interact with monocytes inhibiting the immune response in vitro. ${ }^{56}$

The suitability of conditions in the gastrointestinal tract for toxin production may depend on diet and other factors. Toxin absorption is also affected by many variables, some of which are host-related whereas others are not. For example, the presence of one organism can enhance absorption of toxin produced by another organism ${ }^{5}$ or one toxin can affect the receptor sites of another, so affecting the permeability of the intestinal mucosa to toxins. ${ }^{57}$ Some mothers' milk contains secretory immunoglobulin type A (sIgA) antibody that neutralises $C$. difficile toxin. ${ }^{58}$ Mothers' colostrum has also been shown to contain antibodies to $V$. cholerae toxin and rotavirus, ${ }^{59} E$. coli enterotoxin $^{60}$ and $C$. botulinum. ${ }^{61}$ The presence of these enterotoxins in the sera of babies, and antibodies to them in mothers' milk, means that these enterotoxins are absorbed into the body like botulinum toxin. However, whether the presence of the enteric bacteria and their toxins is detrimental to the host will depend on the toxigenicity of the strains, the concentration of the toxin, whether the toxin is absorbed by the host and the immunological maturity and defences of the infant, and, in very young babies, on the immunological protection from the mother, which in turn depends on the immunological competence of the mother. The unique age-related peak incidence of SIDS and of infant botulism ${ }^{3,62}$ correlates with the introduction of solid foods to the infant diet, ${ }^{63}$ as well as the gap in their immunological development between protection from maternal antibodies and the development of their own antibodies. ${ }^{64}$ The association with solid food intake is probably related to the increased exposure to contamination by enterotoxigenic bacteria (mostly animal commensals) in these foods and during feeding procedures. IgM levels from some SIDS cases were elevated, suggesting an active immunological reaction. ${ }^{65}$

C. difficile toxin has been shown to cause infant rhesus monkeys to die rapidly and quietly, a death clinically and pathologically consistent with human 
SIDS. ${ }^{66}$ Guinea-pigs sensitised per os to milk proteins also died quietly under simulated sleep conditions. ${ }^{67}$ High levels of dopamine and noradrenaline in the carotid bodies of cot-death babies have been reported $^{68}$ although not confirmed. ${ }^{69}$ Further, postmortem findings have been interpreted as indicating that the babies die in shock..$^{19,70}$

Our results strongly suggest that in some SIDS cases, the trigger mechanism that could initiate the cascade of reactions that leads to a silent shock death is the absorption of adequate amounts of toxins from the intestinal tract. These foreign proteins may not necessarily be only bacterial enterotoxins but may include other bacterial toxins, e.g., C. perfringens ( $\alpha$ to i), viral proteins and cow's milk proteins ${ }^{67}$ in the case of children sensitive to an anaphylactic shock reaction.

Our results led us to formulate the hypothesis that in babies who are not protected immunologically, when conditions in the intestinal tract are favourable to toxigenesis (toxic strains present under suitable conditions), toxin is produced and absorbed and the babies undergo a shock reaction similar to endotoxic shock. ${ }^{17}$ This is possibly one of the major basic mechanisms causing SIDS.

If enteric pathogens and their toxins are an important cause of SIDS, this needs to be reconciled with a number of epidemiological factors that are well recognised as important in SIDS, e.g., the greater incidence of SIDS in formula- or solids-fed than breast-fed babies, ${ }^{71-74}$ in male babies, ${ }^{71,74}$ in winter months, ${ }^{71,74}$ in babies of parents of lower socioeconomic status, ${ }^{71,74}$ in some races ${ }^{71,72,74}$ and in babies sleeping prone..$^{75,76}$ The results in table Va strongly suggest that formula feeding leads to a greater incidence of bacterial contamination and toxin production than breast feeding. ${ }^{52}$ This could result from greater opportunities for contamination with common animal commensals that occur in the hospital and home environment during food preparation and feeding.

Bacterial growth could occur in bottles left in the cot, often for hours, with slow-feeding infants. Greater initial contamination levels from formula ingredients and solids are likely, compared to breast-milk, and are also likely to occur from lower levels of cleanliness in

\section{References}

1. Arnon SS, Damus K, Midura TF, Wood RM, Chin J. Intestinal infection and toxin production by Clostridium botulinum as one cause of sudden infant death syndrome. Lancet 1978 ; 1: $1273-1277$.

2. Arnon SS, Damus K, Chin J. Infant botulism: epidemiology and relation to sudden infant death syndrome. Epidemiol Rev 1981 ; 3: 45-66.

3. Arnon SS. Breast feeding and toxigenic intestinal infections: missing links in crib death? Rev Inf Dis 1984; 6 Suppl 1: S193-S201.

4. Trube-Becker E. Enteral bacterial infection as a possible cause of cot death. Forensic Sci 1978; 11: 171 . lower socio-economic homes. Results shown in table $\mathrm{Vb}$ suggest that male babies may be exposed to conditions that result in a greater incidence of these bacteria, particularly $C$. perfringens and their toxins, than female babies. Sixty-six percent of all babies were formula-fed which suggests that some other factor, e.g., greater food intake, lower stress threshold, a difference in immunological maturity and protection, ${ }^{77}$ or intestinal conditions may be involved. Results shown in table Vc tend to support the higher SIDS rate in autumn and winter.

Enterotoxaemia in young animals is commonly associated with weather chills, winter and changes in diet or to mothers being moved to more succulent (greener) pastures. ${ }^{778}$ This could well result from chills affecting the abdomen and intestinal tract bringing on stress $^{79}$ and changes in intestinal secretions ${ }^{79}$ which affect gastrointestinal $\mathrm{pH}$, growth and conditions for toxin formation.

Lower socio-economic status and poorer education possibly result in less appreciation of the need for hygiene in feeding and attention to cleanliness and temperature control of infant food, increasing opportunities for bacterial contamination and growth. Better education and standards of living would tend to avoid these problems, reducing the disparity in risk under better social conditions between formula-fed and breast-fed babies. Practically all ( $>99 \%$ ) of the SIDS babies studied were of Caucasian origin, so these results do not directly help us to understand the differences in SIDS rates for races. However, in the case of poorer black populations in the USA ${ }^{71}$ and Maoris $^{\text {p3 }}$ in New Zealand, their socio-economic status may affect bacterial contamination sufficiently to explain the higher SIDS rates reported.

Further research with animal models on the effect of the factors indicated above are likely to elucidate how these epidemiological factors exert their effect. Our studies (S. Siarakas, E. Damas and W. G. Murrell; unpublished observations) show that these toxins are absorbed from the intestinal tract of rabbits, affect catecholamine levels and reduce heart rate, blood pressure and breathing, resulting in sudden death.

We thank Dr M. O'Neill and Adrienne Kirby, School of Crop Sciences, the University of Sydney, for statistical advice.
5. Sonnabend OA, Sonnabend WFF, Krech U, Molz G, Sigrist T. Continuous microbiological and pathological study of 70 sudden and unexpected infant deaths: toxigenic intestinal Clostridium botulinum infection in 9 cases of sudden infant death syndrome. Lancet 1985; 1 : 237-241.

6. Laughon B, Kozakewich H, Vawter GF, Yolken R. The role of Clostridium difficile in sudden infant death syndrome. In: Tildon JT, Roeder LM, Steinschneider A (eds) Sudden infant death syndrome. New York, Academic Press. 1983: $557-566$.

7. Murrell TGC, Ingham BG, Moss JR, Taylor WB. A hypothesis concerning Clostridium perfringens type-A enterotoxin (CPE) and sudden infant death syndrome (SIDS). Med Hypotheses 1987; 22 : 401-413. 
8. Reid GM. Sudden infant death syndrome-the role of putrefactive toxins in respiratory paralysis and cerebral coma. Med Hypotheses 1987; 22 : 303-307.

9. Morris JA, Haran D, Smith A. Hypothesis-common bacterial toxins are a possible cause of the sudden infant death syndrome. Med Hypotheses $1987 ; 22: 211-222$.

10. Bettelheim KA, Dwyer BW, Smith DL, Goldwater PN, Bourne AJ. Toxigenic Escherichia coli associated with sudden infant death syndrome. Med J Aust 1989; 151 : 538.

11. Bettelheim KA, Goldwater PN et al. Toxigenic Escherichia coli associated with sudden infant death syndrome. Scand $J$ Infect Dis 1990; 22 : 467-476.

12. Telford DR, Morris JA, Hughes $P$ et al. The nasopharyngeal bacterial flora in sudden infant death syndrome. $J$ Infect 1989; 18: 125-130.

13. Kariks J. Chlamydia trachomatis and SIDS? (letter). Med J Aust 1990; $152: 384$.

14. Lundemose JB, Lundemose AG, Gregensen M, Helweg-Larsen $\mathrm{K}$, Simonsen J. Chlamydia and sudden infant death syndrome. A study of 166 SIDS and 30 control cases. Int $J$ Leg Med 1990; 104: 3-7.

15. Bettelheim KA, Smith $H$, Goldwater $P N$ et al. Sleeping position and cot deaths. Lancet 1991; 338: 192.

16. Stark PL, Lee A. Clostridia isolated from the faeces of infants during the first year of life. $J$ Pediatr $1982 ; 100: 362-365$.

17. Murrell WG, Stewart BJ, O'Neill C, Kariks J. Abstracts of the Annual Meeting of the Australian Society of Microbiology. 1986: P11, 185.

18. Beckwith JB. Observations of the pathological anatomy of the sudden infant death syndrome. In: Bergman AB, Beckwith JB, Ray CG (eds) Sudden infant death syndrome: Proceedings of the second international conference on causes of sudden infant death in infants. Seattle, University of Washington Press. 1970: 83-102.

19. Kariks J. Is shock the mode of death in SIDS? Med Hypotheses 1985; 18: 331-349.

20. Holdeman LV, Cato EP, Moore WEC. Anaerobe laboratory manual, 4th edn. Blacksburg, Virginia, Virginia Polytechnic Institute. 1977.

21. Anon. Methods for the microbiological examination of food. Part 2. Examination for specific organisms. 1.7 Clostridium botulinum and Clostridium botulinum toxin. Standards Association of Australia Addendum No. 1 (June 1976) to AS1766. Part 2 (1976): 2-29 to 2-32.

22. Murrell WG, Stewart BJ. Botulism in New South Wales, 1980-81. Med J Aust 1983; 1: 13-17.

23. Rolfe RD. Diagnosis of Clostridium difficile-associated intestinal disease. CRC Crit Rev Clin Lab Sci 1986; 24: 235-261.

24. Taylor WI. Isolation of Shigellae, I Xylose lysine agars; new media for isolation of enteric pathogens. Am J Clin Pathol $1965 ; 44: 471-475$.

25. Baird-Parker AC. An improved diagnostic and selective medium for isolating coagulase positive staphylococci. $J$ Appl Bacteriol 1962; 25 : 12-19.

26. Kobayashi T, Enomoto S, Sakazaki R, Kuwahara S. A new selective medium for pathogenic vibrios: TCBS agar (modified Nakanishi's agar). Jpn J Bacteriol 1963; 18: 387-391.

27. Anon. Methods for the microbiological examination of food. Part 2. Examination for specific organisms. 1.6 Bacillus cereus. Standards Association of Australia Addendum No. 1 (June 1976) to AS1766. Part 2 (1976); 2-25 to 2-28.

28. Schiemann DA. Synthesis of a selective agar medium for Yersinia enterocolitica. Can $J$ Microbiol 1979; 25: $1298-1304$

29. Anderson JM, Baird-Parker AC. A rapid and direct plate method for enumerating Escherichia coli biotype 1 in food. J Appl Bacteriol 1975: 39: 111-117.

30. Bolton FJ, Robertson L. A selective medium for isolating Campylobacter jejuni/coli. J Clin Pathol 1982; 35:472-476.

31. Harmon SM, Kautter DA, Peeler JT. Improved medium for enumeration of Clostridium perfringens. Appl Microbiol $1971 ; 22$ : 688-692.

32. George WL, Sutter VL, Citron D, Finegold SM. Selective and differential medium for isolation of Clostridium difficile. $J$ Clin Microbiol 1979; 9 : 214-219.

33. Mills DC, Midura TF, Arnon SS. Improved selective medium for the isolation of lipase-positive Clostridium botulinum from feces of human infants. $J$ Clin Microbiol 1985; 21 : 947-950.

34. Steel, RGD, Torrie JH. Principles and procedures of statistics. A biometrical approach. 2nd edn. London, McGraw-Hill International. 1981: 495-502.

35. Brown DF, Twedt RM. Assessment of the sanitary effectiveness of holding temperatures on beef cooked at low temperatures. Appl Microbiol 1972; 24: 559-603.

36. Rey CR, Walker HW, Rohrbaugh PL. The influence of temperature on growth, sporulation, and heat resistance of spores of six strains of Clostridium perfringens. J Milk Food Technol 1975; 38: 461-465.

37. Smith LDS. Factors involved in the isolation of Clostridium perfringens. J Milk Food Technol 1972; 35: 71-76.

38. Cato EP, George WL, Finegold SM. Genus Clostridium prazmouwski. In: Sneath PHA, Mair NS, Sharpe ME, Holt JG (eds) Bergey's Manual of systematic bacteriology, vol 2. Baltimore, Williams and Wilkins. 1986: 1141-1200.

39. Bowman RA, Riley TV. Isolation of Clostridium difficile from stored specimens and comparative susceptibility of various tissue culture cell lines to cytotoxin. FEMS Microbiol Lett $1986 ; 34: 31-35$

40. Traci PA, Duncan CL. Cold shock lethality and injury in Clostridium perfringens. Appl Microbiol 1974; 28: 815-821.

41. Berry PR, Rodhouse JC, Hughes S, Bartholomew BA, Gilbert RJ. Evaluation of ELISA, RPLA, and Vero cell assays for detecting Clostridium perfringens enterotoxin in faecal specimens. J Clin Pathol 1988; 41 : 458-461.

42. Harmon SM, Kautter DA. Evaluation of a reversed passive latex agglutination test kit for Clostridium perfringens enterotoxin. J Food Protect 1986; 49: 523-525.

43. Duncan CL, Strong DH. Experimental production of diarrhoea in rabbits with Clostridium perfringens. Can $J$ Microbiol 1969; 15: 765-770.

44. Stark RL, Duncan CL. Biological characteristics of Clostridium perfringens type A enterotoxin. Infect Immun 1971; 4: 89-96.

45. Stelma GN, Wimsatt JC, Kauffman PE, Shah DB. Radioimmunoassay for Clostridium perfringens enterotoxin and its use in screening isolates implicated in food-poisoning outbreaks. J Food Protect 1983; 46: 1069-1073.

46. van Damme-Jongsten $\mathrm{M}$, Wernars $\mathrm{K}$, Watermans S. Cloning and sequencing of the Clostridium perfringens enterotoxin gene. Antonie van Leeuwenhoek 1989; 56: 181-190.

47. Delmee M, Verellen G, Avesani V, Francois G. Clostridium difficile in neonates: serogrouping and epidemiology. Eur $J$ Pediatr 1988; 147: 36-40.

48. Snyder ML. The normal faecal flora of infants between two weeks and one year of age. J Infect Dis $1940 ; 66: 1-16$.

49. Lindsay JA, Sleigh RW, Ghitgas C, Davenport JB. Purification and properties of an enterotoxin from a coatless spore mutant of Clostridium perfringens type A. Eur J Biochem 1985; 149: 287-293.

50. Murrell WG, Ouvrier RA, Stewart BJ, Dorman DC. Infant botulism in a breast-fed infant from rural New South Wales. Med J Aust 1981; 1: 583-585.

51. Stark PL, Lee A, Parsonage BD. Colonization of the large bowel by Clostridium difficile in healthy infants: quantitative study. Infect Immun 1982; 35: 895-899.

52. Cooperstock MS, Steffen E, Yolken R, Onderdonk A. Clostridium difficile in normal infants and sudden infant death syndrome: an association with infant formula feeding. Pediatrics 1982; 70: 91-95.

53. Mardh, PA, Helin I, Colleen I, Oberg M, Holst E. Clostridium difficile toxin in faecal specimens of healthy children and children with diarrhoea. Acta Paediatr Scand 1982; 71: 275-278.

54. Torres JF, Cedillo R, Sanchez J, Sillman C, Giono S, Munoz O. Prevalence of Clostridium difficile and its cytotoxin in infants in Mexico. J Clin Microbiol 1984; 20 : 274-275.

55. Gurwith MJ, Langston C, Citron DM. Toxin-producing bacteria in infants. Lack of an association with sudden infant death syndrome. Am $J$ Dis Child 1981; 135: 1104-1106.

56. Daubener W, Leiser E, von Eichelstreiber C, Hadding V. Clostridium difficile toxins $\mathrm{A}$ and $\mathrm{B}$ inhibit human immune response in vitro. Infect Immun 1988; 56: 1107-1112.

57. Wilkins T, Krivan H, Stiles B, Carman R, Lyerly D. Clostridial toxins active locally in the gastrointestinal tract. In: CIBA 
Foundation Symposium 112. Microbial toxins and diarrhoeal disease. London, Pitman. 1985; 230-241.

58. Wada N, Nishida N, Iwaki $\mathrm{S}$ et al. Neutralising activity against Clostridium difficile toxin in the supernatants of cultured colostral cells. Infect Immun 1980; 29: 545-550.

59. Simhon A, Yolken RH, Mata L. S-IgA cholera toxin and rotavirus antibody in human colostrum. Acta Paediatr Scand 1979; 68: 161-164.

60. Stoliar OA, Kaniecki-Green E, Pelley RP, Klaus MH, Carpenter CCJ. Secretory IgA against enterotoxins in breastmilk. Lancet 1976; 1 : 1258-1261.

61. Arnold RR, Mills DC, Arnon SS. Natural secretory IgA antibodies to Clostridium botulinum in human milk whey. Abstract. 13th International Congress of Microbiology, Boston, 1982: 34.

62. Arnon SS, Chin J. The clinical spectrum of infant botulism. Rev Infect Dis $1979 ; 1:$ 614-624.

63. Pottgen P, Hillegass LM. Botulism and sudden infant death. Lancet 1977; 1 : 147-148.

64. Hobbs JR. Primary immune paresis. In: Adinolfi M (ed) Immunology and development (Clinics in Developmental Medicine No 34). London, Heinemann. 1969: 114-158.

65. Clausen CR, Ray CG, Hebestreit N, Eggleston P. Studies of the sudden infant death syndrome in King County, Washington. IV Immunologic studies. Pediatrics 1973; 52: 45-51.

66. Arnon SS, Mills DC, Day PA, Henrickson RV, Sullivan NM, Wilkins TD. Rapid death of infant rhesus monkeys injected with Clostridium difficile toxins A and B: physiologic and pathologic basis. J Pediatr 1984; 104: 3440.

67. Coombs RRA, McLaughlan P. The modified anaphylactic hypothesis for sudden infant death syndrome. In: Tildon JT, Roeder LM, Steinschneider A (eds) Sudden infant death syndrome. New York, Academic Press. 1983: $531-538$.

68. Perrin DG, Cutz E, Becker LE, Bryan AC, Madapallimatum A,
Sole MJ. Sudden infant death syndrome: increased carotidbody dopamine and noradrenaline content. Lancet 1984; 2: 535-537.

69. Lack EE, Perez-Atayde AR, Young JB. Carotid bodies in sudden infant death syndrome: a combined light microscopic, ultrastructural, and biochemical study. Pediatr Pathol 1986; 6: 335-350.

70. Kariks J. Cardiac lesions in sudden infant death syndrome. Forensic Sci Int 1988; 39: 211-225.

71. Valdes-Dapena MA. Sudden and unexpected death in infancy: a review of the world literature 1954-1966. Pediatrics 1967; 39: 123-138.

72. Valdes-Dapena MA. Sudden infant death syndrome: a review of the medical literature 1974-79. Pediatrics 1980; 66: 597-614.

73. Tonkin S. Epidemiology of SIDS in Auckland, New Zealand. In: Robinson RR (ed) "SIDS 1974". Proceedings of the Francis E. Camps International Symposium on Sudden and Unexpected Deaths in Infancy. Toronto, Canadian Foundation for the Study of Infant Deaths. 1974: 169-175.

74. Dwyer T, Ponsonby AL. Sudden infant death syndromeinsights from epidemiological research. $J$ Epidemiol Community Health 1992; 46: 98-102.

75. Beal S. Sudden infant death syndrome related to sleeping position and bedding. Med J Aust 1991; 155: 507-508.

76. Dwyer T, Ponsonby AL, Gibbons LE, Newman NM. Prone sleeping position and SIDS: Evidence from recent casecontrol and cohort studies in Tasmania. $J$ Paediatr Child Health 1991; 27: 340-343.

77. Paul WE. Fundamental Immunology, 2nd edn. New York, Raven Press. 1989; 836.

78. Trinea JC (ed). CSL Veterinary handbook. Blackburn, Vic., Dominican Press. 1979: 49-53.

79. Tannock GW. Effect of dietary and environmental stress on the gastrointestinal microbiota. In: Hentges DJ (ed). Human intestinal microflora in health and disease. New York, Academic Press. 1983: 517-539. 